\title{
How can gender signal employee qualities in retailing?
}

\begin{abstract}
The occupational structure in retail employment is known to be gendered, such that women tend to occupy 'softer' social roles, while men tend to occupy 'harder' physical and technical roles. This article presents an integrative model that illustrates the balance of KSAOs (knowledge, skills, abilities, and other personality characteristics) and retail sectors between male and female retail employees, and explains how gender can signal employee qualities in the retail sector. The empirical analysis uses data from a survey of 702 respondents employed across 40 ANZSIC (Australian New Zealand Standard Industrial Classification) retail categories. Based on signalling theory, the findings suggest that an employee's gender can be an unintentional signal for unobservable qualities in retail employment, which has implications for customer service, human resource management, and gender discrimination.
\end{abstract}

Paper classification: Research paper

Keywords: Gender, Employment, Retailing, Discrimination 


\section{Introduction}

Signalling theory explains how unobservable qualities can be communicated by observable qualities, thus reducing information asymmetry between two parties (Spence, 2002). Early research on signalling theory from Spence (1973) gives the example of how high-quality job applicants distinguish themselves from low-quality prospects by using higher education to signal high quality. A more recent example from Zhang and Wiersema (2009) shows how CEOs signal the unobservable quality of their firms to potential investors via financial statements, which are observable. The use of signalling theory has gained momentum in the management literature in recent years as scholars have expanded the range of potential signals and the contexts in which signalling occurs (Connelly et al., 2011). Signalling is not always intentional, but can be unintentional and negative (Janney and Folta, 2003; Daily et al., 2005; Perkins and Hendry, 2005). In fact, a sender can communicate a wide range of signals without being aware of it (Spence, 2002). Because signallers and receivers have partially competing interests, inferior signallers have incentive to cheat by intentionally producing dishonest signals (Johnstone and Grafen, 1993). Examples of this are falsified company reports to prospective investors, or fake university degrees used by job applicants. Conversely, honest signals (Durcikova and Gray, 2009) accurately represent the underlying qualities of the signal. Drawing from this theory, given that that the occupational structure in retail employment is gendered (e.g. Sparks, 1991; Fischer, Gainer, and Bristor, 1997; Taylor and Tyler, 2000; Korczynski, 2002; Lynch, 2002; Foster, 2004; Pettinger, 2005), this study proposes that the simple and observable characteristic of being male or female can be an unintentional and honest signal for unobservable qualities in the retail employment context.

\section{Aim and need for study}

Recent research in retailing has focused on gender differences among consumers (e.g. Cambra-Fierro et al., 2013; Das, 2014; Jackson et al., 2011; Lahari and Leclerc, 2013; McNeill and Douglas, 2011; Mortimer and Clarke, 2011; Shepard at al., 2014), with a paucity of recent research on gender differences among service providers in retailing. A prominent difference between the retail workforce and the general workforce is that it 
hires a higher percentage of women (Sparks, 1992; Brockbank and Airey, 1994; Pilcher, 2007). A substantial number of studies report that women tend to occupy 'softer' socialoriented roles (e.g. Sirianni and Negrey, 2000; Taylor and Tyler, 2000; Lynch, 2002; Kerfoot and Korczynski, 2005; Pettinger, 2005; Kmec, 2008; Chang and Travaglione, 2011). On the other hand, men tend to occupy 'harder' technical-oriented roles (Brockbank and Airey, 1994; Broadbridge, 1997; Lynch, 2002; Schmidt and Parker, 2003; Harris, Foster, and Whysall, 2007; Chang and Travaglione, 2011). Extant findings in this area show overlap, and an integrative model can help explain such differences more systematically. Therefore, this article presents an integrative model to illustrate the balance of KSAOs (knowledge, skills, abilities, and other personality characteristics) and retail sectors between male and female retail employees by pairing a literature review with empirical data, and explains how gender can signal employee qualities in the retail sector. The empirical component uses data from a survey of 702 respondents employed across 40 ANZSIC (Australian New Zealand Standard Industrial Classification) retail categories (e.g. groceries, clothing, automobiles, hardware, restaurants). The next sections will review extant literature, state the objective and hypotheses, explain the empirical data, discuss the results, and present the model.

\section{Literature review}

Gender segregation in employment

A substantial body of literature identifies occupational differences between men and women in the workplace. Occupational segregation occurs when workers are excluded from certain jobs and are over-represented in others based on factors such as race, gender or national origin (Gabriel and Schmitz, 2007). Some articles suggest that gender stereotypes affect employers' perceptions of male and female workers (Cejka and Eagly, 1999; Ridgeway and Correll, 2004; Gabriel and Schmitz, 2007). For instance, Cejka and Eagly (1999) comment that many occupations are almost totally dominated by one sex. There are more male-dominated occupations than female-dominated occupations and that the female occupations tend to be lower paying, with associated lower status and fewer advancement opportunities (Tikka, 1999). Gabriel and Schmitz (2007) noted that occupational differences between men and women are persistent, in that traditional blue- 
collar occupations continue to be male-dominated, while women remain concentrated in service-oriented and clerical occupations. According to Brockbank and Airey (1994), 'occupational segregation' is the tendency for women to work in particular sectors of the labour market which are exclusively, or almost exclusively, staffed by women, with the retail industry identified as a pertinent example. Gender-specific characteristics can explain occupational differences. Generally, men are perceived to be more suited to technical, practical, and physically demanding roles (Deaux, 1984; Lynch, 2002; Wanrooy et al. 2008; Chang and Travaglione, 2011) and women are perceived to be more suited to social interaction roles, such as customer service (Marchington, 1995). Such differences form a basis for gender diversity in employment. For example, Pettinger (2005) found that men dominated in employment sectors in which goods were heavy or valuable, or, when the clientele was largely male, while Regine (2011) found that 'soft' skills such as relational intelligence, emotional intelligence, holistic perspective, inclusion, empathy, and intuition are more developed in women. Additionally, McCollKennedy, Daus, and Sparks (2003) noted that men are thought to be more assertive while women are more nurturing, and Finch and Groves (1983) noted the natural ability for women to care for others. Service roles have been reported to be filled by women based on their emotional skills (Hochschild, 1983; Matilla, Grandey, and Fisk, 2003; Chang and Travaglione, 2011). Anker (1997) noted that neo-classical/human capital theories correctly point out how women are less qualified than men for certain occupations because of differences in their level of education and years of experience. Similarly, Ngo (2000) explains that prestigious jobs are considered to be male-typed and found that women are more likely to be represented in sales, clerical and administrative positions.

\section{Women in retail employment}

The retail employment sector is known to be dominated by women (Sparks, 1992; Brockbank and Airey, 1994; Cranford, Vosko, and Zukewich, 2003; Pilcher, 2007). A substantial number of studies report that women are more suited to service roles (Sirianni and Negrey, 2000; Taylor and Tyler, 2000; Lynch, 2002; Kerfoot and Korczynski, 2005; Pettinger, 2005; Kmec, 2008). For example, Pettinger (2005) explains that the gendering of retail employment lies with the feminisation of customer-service work, due to the 
emotion management aspect of the work. This is reiterated by Toynbee (2006), who notes that women are disproportionately represented in the service sector's five 'C's': 'Catering; Cashier or Checkout, Clerical, Cleaning and Caring,' most of which require a degree of emotional labouring. Similarly, Lynch (2002) found that departments such as checkouts and administration tend to be dominated by women working part-time. Sparks (1992) noted that in the past, the expansion of the female component in retail employment has been associated with the increase in part-time employment. A substantial number of studies show that the majority of part-time workers are female (e.g. Freathy and Sparks, 1995; McIntyre, 2000; Crompton, 2002; Atkinson and Hall, 2009; Chang and Travaglione, 2011). Furthermore, a range of studies show that female retail employees are more likely to seek out flexible work due to domestic responsibilities such as child care and home-related commitments (for example, Brockbank and Airey, 1994; Simpson, Dawkins, and Madden, 1997; Bu and McKeen, 2001; Ngo, 2002; Warren, 2004; McDonald, Bradley, and Brown, 2008). This is to the extent that some women are willing accept inferior employment terms and conditions to accommodate their child-care and domestic obligations (Brockbank and Airey, 1994). Similarly, Tomlinson (2007) pointed out that part-time work is highly gendered and often of low-status which has serious consequences for women's economic independence, financial security, and quality of working life.

\section{Gender and product connotations}

A substantial amount of research indicates that gender patterns exist in retail employment (Sparks, 1991; Fischer et al., 1997; Taylor and Tyler, 2000; Korczynski, 2002; Lynch, 2002; Foster, 2004; Pettinger, 2005). Fischer et al. (1997) stated that gender stereotypes, or in-group bias/homophily, may exist and influence evaluations of service quality, depending on whether the service provider is male or female. That is, in some service settings, women expect to receive better service from women, and men from men. Foster (2004) suggests that certain retail sectors are 'gendered'; that is, the products they sell have stereotypical male connotations, such as car sales or men's fashion, or stereotypical female associations, like cosmetic sales and ladies' fashion and, very often, the gender of customer-facing staff reflects this association. Research by Brockbank and Airey (1994) 
found that in one particular company which retails maternity and child-care products exclusively, 93 per cent of the employees were women. In the example for DIY (Do-ItYourself) stores, Sparks (1991) found that male customers perceived male staff to have better technical knowledge and greater physical competency when handling products than female staff, and often preferred to seek advice from male rather than female staff, with a particular preference toward older male staff. This was due to the assumption that men were more likely to have carried out home improvements or to have worked as a trade person than women. This finding is also supported by Foster (2004), who argues that DIY is an activity predominately undertaken by men and many items sold in this sector have stereotypically masculine connotations, such as power tools and electrical, plumbing and building products. If women were employed in DIY stores, they tended to be located on the checkouts, returns desk and in "non-expert" roles, or within more traditionally 'feminine' product areas, such as decorative items and gardening, and in showrooms (Sparks, 1991). This finding is consistent with Korczynski’s (2002) research, which found that in DIY stores, trade experts were male and most checkout operators were female. This appears to be a result of gender assumptions which are inherent within certain roles. Even in earlier research dating over two decades ago, men were perceived to possess more advanced retail skills than women. For example, Bradley (1989: 232) stated "...the sale of a carpet is considered to involve certain defined skills, whereas the sale of hosiery is not. Men predominate in carpet departments; women in hosiery.”

\section{The 'feminisation' of service}

Pettinger (2005) noted that gender assumptions are embedded in the workplace and in employment relations in the retail industry in a unique way: female sales assistants tend to serve female customers with products that are culturally 'feminine'. Notwithstanding, women were also more likely to work in men's departments than men in women's departments, because of the way the occupation of sales assistant is feminised. In addition, the concept of female staff serving men can imply a degree of sexualisation associated with their roles. For example, Hochschild (1983) suggests that the role of female flight attendants are 'sexualised' through the use of advertising slogans such as 'Fly me, you'll like it.' Hochschild comments that this could imply that female flight 
attendants not only had to be 'unfailingly helpful and open to requests' but also should 'respond to the sexual fantasies of passengers' by acting in a 'sexy' manner and flirting with customers as though their behaviour was not 'intrusive or demeaning'. Hochschild also highlights the contrast between genders by commenting that women 'enhance the customer's status' while men 'deflate the customer's status', giving the example that debt collectors are typically male and required 'open aggression'. McGauran (2000) points out that women are more likely to be employed based on their appearance, and that women are considered better than men at cleaning and stocking goods and at selling to other women. Adkins (1995) points out that the aesthetic criteria for recruitment in a hotel she studied were highly gendered, requiring female employees to be 'attractive'. Pettinger's (2005: 474) study found that female retail assistants were required to look feminine through the use of particular 'make-up' application, 'hair' and 'self-presentation'. Kerfoot and Knights (1994) claim that 'a nice mumsy face at the desk' would both increase sales and smooth the flow of production. Correspondingly, Taylor and Tyler (2000) found that male managers recruiting telesales staff made stereotypical gendered assumptions about women possessing a 'natural' ability to 'chat' and build up a 'rapport' with others. Kerfoot and Korczynski (2005) postulate that gender stereotypes about women's 'proper' place in relation to paid work and their presumed attachment to socalled 'softer' skills in service work reinforces and reproduces gender division in the workplace.

\section{Gender stratification}

Research shows that gender differences exist in retail management positions (Brockbank and Airey, 1994; Lynch, 2002; Schmidt and Parker, 2003; Broadbridge, Maxwell, and Ogden, 2006; Gabriel and Schmitz, 2007; Harris, Foster, and Whysall, 2007). While female employees dominate the retail sector, this dominance is generally in nonmanagerial positions, with management positions dominated by men (Brockbank and Airey, 1994; Broadbridge, 2007; Harris et al., 2007). Where women are employed in management positions, they are more likely to be represented in junior and middle management positions (Broadbridge et al, 2006), while senior management and director level positions in retailing are largely occupied by men (Schmidt and Parker, 2003; 
Maxwell and Ogden, 2006). If women are employed in a managerial role, Brockbank and Airey (1994) suggest that these women are believed to be more likely to have a better understanding of their predominantly female staff and customers, and possess a greater ability for developing relationships with them. Additionally, Becker, Ayman, and Korabik (2002) found that female managers considered to be 'good' bosses seem to be characterized by their subordinates as having stereotypical masculine traits. Notwithstanding, the traditional view postulates that men are more capable than women at work; hence they tend to occupy more important positions, with women largely occupying subordinate roles. Bradley (1989) argues that women and men's participation in retailing has its roots in the onset of capitalism and the existence of male trade union bargaining power which was used to define certain jobs/areas as skilled and kept as male preserves.

According to Broadbridge (1997), where skill and knowledge are perceived to be required, men prevail, whereas if women are found in the traditionally male sectors of retailing they are employed as counter assistants or cash clerks. Similarly, Lynch (2002) points out that those retail jobs defined as 'peripheral' and 'low skill' were predominately filled by women, whereas men filled occupations considered to be 'skilled', such as management positions. The reported paucity of women in retail management positions (for example, Lynch, 2002; Schmidt and Parker, 2003; Gabriel and Schmitz, 2007; and Harris et al. 2007) has been reported be contributed by the unwillingness of female employees to fill management positions than as a result of gender discrimination. For example, Gabriel and Schmitz (2007) suggest that the predominance of men in senior management is more likely to be voluntary, and Harris et al. (2007) found that half of female part-time retail employees surveyed were not seeking promotion. In Gabriel and Schmitz's (2007) study of gender differences among workers, it was found that while gender differences in occupational attainment persists, these differences are the result of voluntary choices made by men and women and from long-term changes in labour markets, such as the simultaneous growth of white-collar occupations and women's labour force participation rates. However, research by Kerfoot and Knights (1994) points out that some employment practices deliberately target 'mature' women returning to the 
workforce who were discriminately employed in low-paid, low-status work outside the main organisational career structure.

\section{Hypotheses}

The integrative model presented in this paper will comprise overlapping findings from the foregoing literature review and an empirical component as a corroborative measure. Hence, the hypotheses enunciated below are based on the foregoing literature review.

H1. Technically oriented retail sectors are dominated by males

H2. Physically oriented retail sectors are dominated by males

H3. Socially oriented retail sectors are dominated by females

H4. Aesthetically oriented retail sectors are dominated by females

\section{Research design}

\section{Sample and data}

The data used for this study comes from the 2009 Australia at Work survey. Conducted by the Australian Workplace Research Centre at the University of Sydney, this is part of a longitudinal study that tracked the experiences of the Australian labour force. The study is funded by the Australian Research Council and Unions NSW, and is advised by a board consisting of labour market and industrial relations academics from around Australia. The 2009 survey documented the findings of a total of 6,801 respondents via telephone interviews of up to 20 minutes and is compliant to privacy principles under the Association of Market and Social Research Organisations. Participation was anonymous and voluntary, and the incentive for participating was a one in 40 chance in winning an iPod. The sample is weighted, using population estimates from the ABS (Australian Bureau of Statistics) Labour Force Survey, according to age, sex, location, labour force status and union membership. The relevant gender and retail industry classification subset of the data used for this study consists of 702 respondents (300 men and 402 women) employed across 40 ANZSIC (Australian New Zealand Standard Industrial Classification) categories that make up the retail sector. Among the men, 56.7 per cent are aged 25 and over, 58.4 per cent are in full-time positions, 28.7 per cent have 
dependent children, 14.3 per cent have university degrees, and 19.9 per cent are in managerial positions. Among the women, 60.7 per cent are aged 25 and over, 28.9 per cent are in full-time positions, 35.3 per cent have dependent children, 13.4 per cent have university degrees, and 12.7 per cent are in managerial positions.

\section{Analysis}

Cross tabulation was applied using the data to analyse the distribution of males and females employed across the 40 ANZSIC retail sectors. Chi square $\left(\chi^{2}\right)$ testing was employed to determine statistical significance between variables within the table used in the analysis. This tests the association between two categorical samples for the likelihood that the distribution is due to chance or probability. Statistical significance at the $\mathrm{p}<0.05$ level was confirmed in the table analysed, which confirms that these results are statistically conclusive and are unlikely to have occurred by chance.

\section{Results}

The data shows that different retail sectors were found to have different gender characteristics. Among the retail sectors, the grocery and supermarket sector is the largest employer, employing 18.2 per cent of the total of 702 respondents sampled. This is followed by cafes and restaurants at 9.3 per cent, accommodation at 8.0 per cent, takeaway food at 7.0 per cent and department stores at 5.6 per cent. Female employees formed the majority of overall retail employment, making up 57.3 per cent of all employees, which is consistent with findings from previous studies (Sparks, 1992; Brockbank and Airey, 1994; Cranford, Vosko, and Zukewich, 2003; Pilcher, 2007). Certain retail sectors were found to be dominated by male employees. The most maledominated category is electric and electronic related goods ${ }^{1}$ with 81.0 per cent being male employees, followed by garden supplies at 80.0 per cent, motor vehicle and parts ${ }^{2}$ at 78.6 per cent, hardware and building supplies at 63.0 per cent, and sport and camping goods at

1 Comprising of three sectors a) electrical electronic and gas appliance retailing b) computer and computer peripheral retailing c) other electrical and electronic goods retailing

2 Comprising of four sectors a) car retailing b)motor cycle retailing c) trailer and other motor vehicle retailing d) motor vehicle parts retailing 
60 per cent. Compared to the sectors that females dominate in, these sectors are more technically and physically oriented, providing support for hypotheses 1 and 2 . These findings suggest that retail sectors that involve higher levels of technical knowledge and physical effort tend to be staffed by males, which corroborates the findings of Broadbridge (1997), Sparks (1991), Korczynski (2002), Lynch (2002), Foster (2004), and Pettinger (2005).

In those sectors in which female employees dominated, the retail category of clothing employed 85.7 per cent women, followed by pharmaceutical, cosmetics, and toiletries at 82.1 per cent, department stores at 69.2 per cent, newspaper and books at 68.2 per cent, takeaway food at 65.3 per cent, supermarkets at 64.1 per cent, and cafes and restaurants at 63.1 per cent. Compared to the sectors that males dominate in, these sectors are more socially and aesthetically oriented, providing support for hypotheses 3 and 4 . The finding that female employees dominate in areas in which customers are more likely to be female, such as clothing, cosmetics, and toiletries, has been documented by Fischer et al. (1997), Foster (2004), and Pettinger (2005). The identified sectors of takeaway food, supermarkets, and cafes and restaurants where female employees dominate tend to be classified as less skilled positions, frequently check-out related, and tend to be part-time posts, corroborates findings from Broadbridge (1997), McGauran (2000), Lynch (2002), Korczynski (2002), and Pilcher (2007).

\section{Discussion and model}

This study sought to explain how employee gender can be an unintentional and honest signal for employee qualities in retail, based on a review of extant literature supported by empirical data. The review identified and aggregated gender-specific attributes, which form part of the model. The empirical findings, which form the remaining part of the model, identified that specific patterns of male and female employment exist among different retail sectors in Australia. Female employees were found to dominate retail sectors that involved 'softer' social-oriented skills such as; clothing, pharmaceutical goods, cosmetics and toiletries, departmental stores, newspaper and books, takeaway food, supermarkets, and cafes and restaurants, while male employees were found to 
dominate retail sectors that involved 'harder' technical-oriented skills such as; electrical and electronic goods, garden supplies, motor vehicles and parts, hardware and building supplies, and sport and camping goods (see Table 1).

$<$ Insert Table 1 here $>$

The finding that men and women respectively occupy 'hard' and 'soft' roles is not new, and serves to corroborate extant literature in the contemporary context. However, these findings identify how gender-specific retail sectors are distributed between 'hard' and 'soft' skills, and how employee gender is an observable signal for such unobservable attributes. These empirical findings are paired with the literature review to present an integrative model of factors explaining gender in retail employment (see Figure 1).

$<$ Insert Figure 1 here $>$

The model identifies how KSAOs and retail sector roles are distributed between men and women. These findings in the retail context are relevant to service work. Kerfoot and Korczynski (2005) highlight the importance of understanding the ways in which customers are implicated in the production of gender difference and the structuring of service work. Customers often rely on the behaviour of service employees when judging the quality of service (Hennig-Thurau, 2004) and businesses that are more customer oriented have been found to perform better than those who do not (e.g. Narver and Slater, 1990; Jaworski and Kohli, 1993; Donovan et al., 2004). Hence, matching the right employees to specific retail roles can improve customer service. For example, appearance and attitude were found to be important in hospitality roles (Martin and Grove, 2002), with 'soft' skills noted to be more important than 'hard' skills (Burns, 1997). Relevant to Hennig-Thurau's (2004) four dimensions of Customer Orientation Service Employees (COSE), namely technical skills, social skills, motivation, and decision marking authority, our findings infer that the dimension of technical skills are predominately male, while social skills are predominately female. Similarly, service quality has been split into two dimensions, being the outcome (technical quality) and 
process (service delivery) (Grönroos, 1984; Parasuraman, Zeithaml, and Berry, 1985). In the retail context, our findings infer that male employees are more oriented to the outcome dimension, while female employees are more oriented to the process dimension. Further, Gummesson (1987) defined two dimensions of relationship quality, being professional relations (competence) and social relations (interaction). Between these dimensions, our findings in the retail context infer that male employees are more oriented to professional relations, while female employees are more oriented to social relations. This also corresponds to research in customer service noting that women are processoriented while men are outcome-oriented (Iacobucci and Ostrom, 1993; Matilla et al. 2003; Mathies and Burford, 2011).

\section{Conclusion}

The model presented explains how KSAOs of male and female employment are distributed among retail sectors, and suggests that the simple and observable characteristic of being male or female can be an unintentional and honest signal for unobservable qualities based on signalling theory. The findings have implications for workforce planning, evaluation, and gender discrimination. On one hand, the model can be used to guide employers in workforce planning and evaluation. On the other, this implies that employees can potentially be stereotyped or discriminated against based on the simple observation of their gender. Mathies and Burford (2011) found that the interpretation of good customer service is influenced by the gender of the employee, noting that customers may expect, and respond better to staff of the 'appropriate' gender.

\section{Managerial implications}

The model has the potential to help practitioners in retail organisations make genderbased considerations in recruitment and evaluation programs and practices, which can improve customer service and organisational performance. Additionally, this model can facilitate an improved person-job fit based on inherent gender attributes such as physical ability in men and emotional skills in women, which can improve employee satisfaction and retention (Chatman, 1991). The model can also be used to help employees assess which retail roles are more suitable based on an assessment of their own personal 
attributes. This is expected to be useful under current challenging retail conditions and declining retail employment, which threatens labour market access for those in precarious positions.

\section{Research limitations}

A few limitations should be noted in our study. The attributes identified in the model are derived from a significant review of extant literature but are by no means exhaustive. Additionally, these attributes between females and males can be subjective in nature given the diverse circumstances, personalities, and behaviours of individuals. Finally, the retail sectors identified in the empirical component of the model is based on an Australian sample, which may limit the context of the findings. 


\section{FIGURES AND TABLES}

\section{Figure 1. Aggregated balance of KSAOs between male and female retail employees}

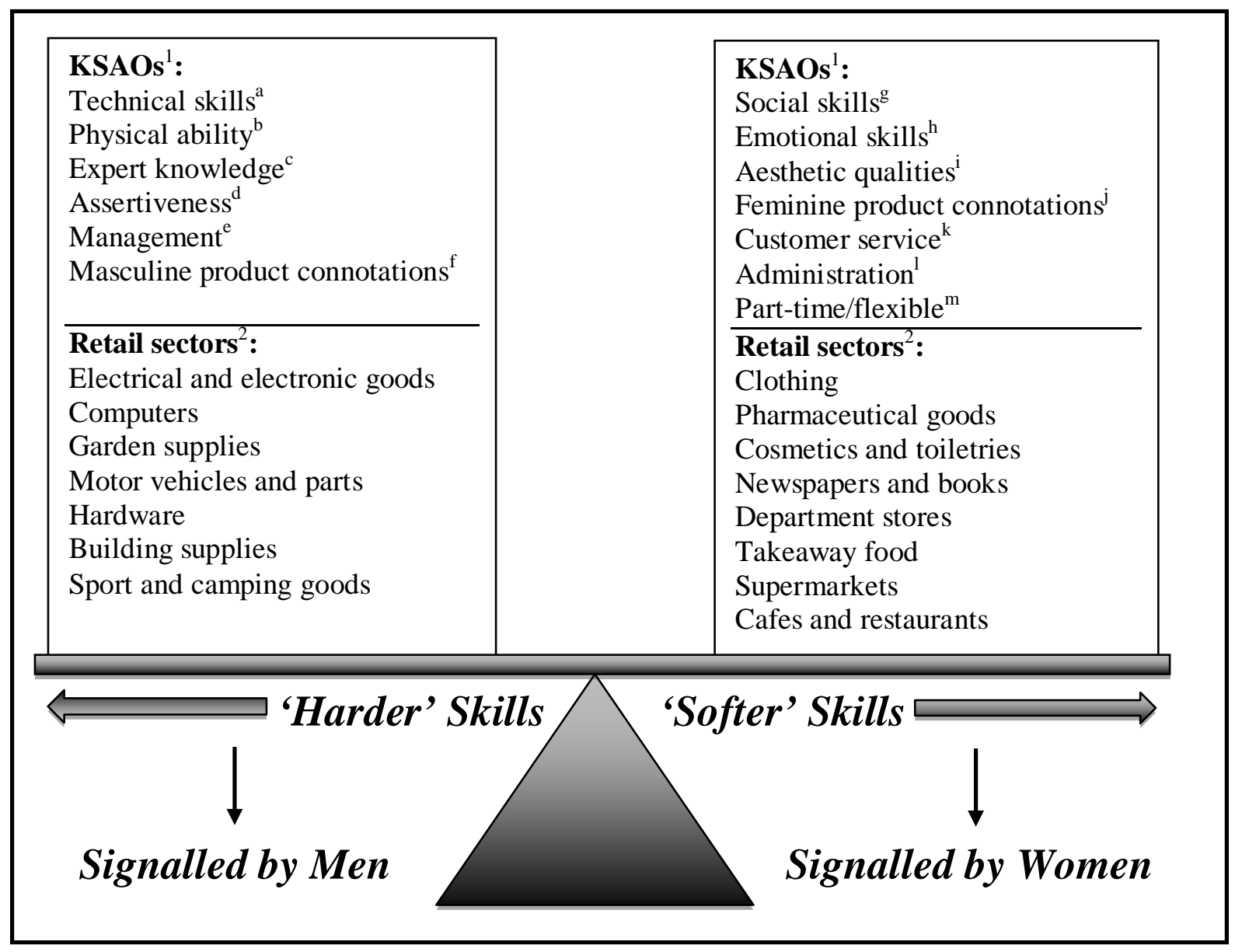

1. Reported in extant literature:

a) Deaux, 1984; Brockbank and Airey, 1994; Broadbridge, 1997; Lynch, 2002; Schmidt and Parker, 2003; Harris, et al., 2007; Chang and Travaglione, 2011

b) Deaux, 1984; Sparks, 1991; Lynch, 2002; Pettinger, 2005; Wanrooy et al. 2008; Chang and Travaglione, 2011

c) Sparks, 1991; Broadbridge, 1997; Korczynski, 2002

d) Hochschild, 1983; McColl-Kennedy, et al., 2003

e) Brockbank and Airey, 1994; Lynch, 2002; Schmidt and Parker, 2003; Broadbridge, et al., 2006;

Broadbridge, 2007; Gabriel and Schmitz, 2007; Harris, et al., 2007

f) Sparks, 1991; Fischer et al., 1997; Foster, 2004; Bradley, 1989; Korczynski, 2002; Pettinger, 2005

g) Sirianni and Negrey, 2000; Taylor and Tyler, 2000; Lynch, 2002; Kerfoot and Korczynski, 2005;

Pettinger, 2005; Kmec, 2008

h) Finch and Groves, 1983; Hochschild, 1983; Taylor and Tyler, 2000; Matilla et al., 2003; McCollKennedy, et al., 2003; Regine, 2011; Pettinger, 2005; Pilcher, 2007; Chang and Travaglione, 2011

i) Adkins, 1995; Kerfoot and Knights, 1994; McGauran, 2000; Pettinger, 2005; Pilcher, 2007

j) Bradley, 1989; Brockbank and Airey, 1994; Fischer, et al., 1997; Foster, 2004; Pettinger 2005 
k) Marchington, 1995; Sirianni and Negrey, 2000; Taylor and Tyler, 2000; Lynch, 2002; Kerfoot and Korczynski, 2005; Pettinger, 2005; Kmec, 2008

l) Ngo, 2000; Lynch, 2002; Korczynski, 2002; Toynbee, 2006; Pilcher; 2007;

m) Brockbank and Airey, 1994; Freathy and Sparks, 1995; Simpson et al., 1997; McIntyre, 2000; Bu and McKeen, 2001; Crompton, 2002; Lynch, 2002; Ngo, 2002; Warren, 2004; Tomlinson, 2007; Atkinson and Hall, 2009; McDonald, et al., 2008; Chang and Travaglione, 2011

2. Derived from empirical data

\section{Table 1. Gender dominated retail sectors}

\begin{tabular}{lc|lc}
\hline Female dominated retail sectors & \% Female & Male dominated retail sectors & \% Male \\
\hline Clothing & 85.7 & Electrical and electronic goods & 81.0 \\
Pharmaceutical/cosmetics/toiletries & 82.1 & Garden supplies & 80.0 \\
Departmental stores & 69.2 & Motor vehicles and parts & 78.6 \\
Newspapers and books & 68.2 & Hardware and building supplies & 63.0 \\
Takeaway food & 65.3 & Sport and camping goods & 60.0 \\
Supermarkets & 64.1 & & \\
Cafes and restaurants & 63.1 & & \\
\hline
\end{tabular}

Table 2: Respondents classified by Retail Sector and Gender ${ }^{1}$

\begin{tabular}{|c|c|c|c|}
\hline \multirow[t]{2}{*}{ Retail Sector } & \multicolumn{2}{|c|}{ Gender } & \multirow[t]{2}{*}{ Total } \\
\hline & Male & Female & \\
\hline \multirow{2}{*}{ Car Retailing } & 12 & 6 & 18 \\
\hline & $66.7 \%$ & $33.3 \%$ & $100.0 \%$ \\
\hline \multirow{2}{*}{ Motor Cycle Retailing } & 3 & 0 & 3 \\
\hline & $100.0 \%$ & $0.0 \%$ & $100.0 \%$ \\
\hline \multirow{2}{*}{$\begin{array}{l}\text { Trailer and Other Motor Vehicle } \\
\text { Retailing }\end{array}$} & 4 & 0 & 4 \\
\hline & $100.0 \%$ & $0.0 \%$ & $100.0 \%$ \\
\hline \multirow{2}{*}{ Motor Vehicle Parts Retailing } & 14 & 3 & 17 \\
\hline & $82.4 \%$ & $17.6 \%$ & $100.0 \%$ \\
\hline \multirow{2}{*}{ Tyre Retailing } & 4 & 0 & 4 \\
\hline & $100.0 \%$ & $0.0 \%$ & $100.0 \%$ \\
\hline \multirow{2}{*}{ Fuel Retailing } & 3 & 3 & 6 \\
\hline & $50.0 \%$ & $50.0 \%$ & $100.0 \%$ \\
\hline \multirow{2}{*}{ Supermarket and Grocery Stores } & 46 & 82 & 128 \\
\hline & $35.9 \%$ & $64.1 \%$ & $100.0 \%$ \\
\hline \multirow{2}{*}{ Fresh Meat Fish and Poultry Retailing } & 5 & 6 & 11 \\
\hline & $45.5 \%$ & $54.5 \%$ & $100.0 \%$ \\
\hline \multirow{2}{*}{ Fruit and Vegetable Retailing } & 3 & 1 & 4 \\
\hline & $75.0 \%$ & $25.0 \%$ & $100.0 \%$ \\
\hline \multirow{2}{*}{ Liquor Retailing } & 9 & 3 & 12 \\
\hline & $75.0 \%$ & $25.0 \%$ & $100.0 \%$ \\
\hline \multirow{2}{*}{ Other Specialised Food Retailing } & 2 & 8 & 10 \\
\hline & $20.0 \%$ & $80.0 \%$ & $100.0 \%$ \\
\hline \multirow{2}{*}{ Furniture Retailing } & 5 & 4 & 9 \\
\hline & $55.6 \%$ & $44.4 \%$ & $100.0 \%$ \\
\hline \multirow{2}{*}{ Houseware Retailing } & 2 & 3 & 5 \\
\hline & $40.0 \%$ & $60.0 \%$ & $100.0 \%$ \\
\hline Manchester and Other Textile Goods & 0 & 1 & 1 \\
\hline
\end{tabular}


Retailing

Electrical Electronic and Gas

Appliance Retailing

Computer and Computer Peripheral

Retailing

Other Electrical and Electronic Goods

Retailing

Hardware and Building Supplies

Retailing

Garden Supplies Retailing

Sport and Camping Equipment

Retailing

Entertainment Media Retailing

Toy and Game Retailing

Newspaper and Book Retailing

Clothing Retailing

Footwear Retailing

Watch and Jewellery Retailing

Other Personal Accessory Retailing

Department Stores

Pharmaceutical Cosmetic and Toiletry

Goods Retailing

Stationery Goods Retailing

Flower Retailing

Other Store-Based Retailing n.e.c.

Non-Store Retailing

Retail Commission-Based Buying and/or Selling

Accommodation

Cafes and Restaurants

Takeaway Food Services

Catering Services

Pubs Taverns and Bars

Clubs (Hospitality)
$0.0 \%$
9

$90.0 \%$

5

$71.4 \%$

3

$75.0 \%$

17

$63.0 \%$

8

$80.0 \%$

9

$60.0 \%$

2

$33.3 \%$

3

$75.0 \%$

7

$31.8 \%$

4

$14.3 \%$

0

$0.0 \%$

0

$0.0 \%$

0

$0.0 \%$

12

$30.8 \%$

5

$17.9 \%$

3

$42.9 \%$

0

$0.0 \%$

5

$23.8 \%$

4

$50.0 \%$

0

$0.0 \%$

25

$44.6 \%$

24

$36.9 \%$

17

$34.7 \%$

8

$50.0 \%$

11

$61.1 \%$

7

$38.9 \%$
$100.0 \%$

$10.0 \%$

2

$28.6 \%$

1

$25.0 \%$

10

$37.0 \%$

2

$20.0 \%$

6

$40.0 \%$

4

$66.7 \%$

1

$25.0 \%$

15

$68.2 \%$

24

$85.7 \%$

3

$100.0 \%$

3

$100.0 \%$

4

$100.0 \%$

27

$69.2 \%$

23

$82.1 \%$

4

$57.1 \%$

1

$100.0 \%$

16

$76.2 \%$

4

$50.0 \%$

1

$100.0 \%$

31

$55.4 \%$

41

$63.1 \%$

32

$65.3 \%$

8

$50.0 \%$

7

$38.9 \%$

11

$61.1 \%$
$100.0 \%$

10

$100.0 \%$

7

$100.0 \%$

4

$100.0 \%$

27

$100.0 \%$

10

$100.0 \%$

15

$100.0 \%$

6

$100.0 \%$

4

$100.0 \%$

22

$100.0 \%$

28

$100.0 \%$

3

$100.0 \%$

3

$100.0 \%$

4

$100.0 \%$

39

$100.0 \%$

28

$100.0 \%$

7

$100.0 \%$

1

$100.0 \%$

21

$100.0 \%$

8

$100.0 \%$

1

$100.0 \%$

56

$100.0 \%$

65

$100.0 \%$

49

$100.0 \%$

16

$100.0 \%$

18

$100.0 \%$

18

$100.0 \%$

$\begin{array}{cccc}\text { Total } & 300 & 402 & 702 \\ & 42.7 \% & 57.3 \% & 100.0 \%\end{array}$


1. $(\mathrm{N}=702)$. A chi square test of significance difference in distribution of respondents across age groups and gender found statistically significant differences between these groups $\left(\chi^{2}=106.95, \mathrm{p}<0.001\right.$, degrees of freedom=39) 


\section{References}

Adkins, L. (1995), Gendered Work: Sexuality, Family and the Labour Market, Buckingham, Open University Press

ABS (Australian Bureau of Statistics) (2012), Year Book Australia 2012, Catalogue 2012.0. Canberra.

Anker, R. (1997), "Theories of occupational segregation by sex: An overview", International Labour Review, Vol. 136 No. 2, pp. 315-339.

Atkinson, C. and Hall, L. (2009), "The Role of Gender in Varying Forms of Flexible Working”, Gender, Work and Organization, Vol. 16 No. 6, pp. 650-666.

Beck, U. (2000), The Brave New World of Work, Cambridge: Polity Press.

Becker, J., Ayman, R., and Korabik, K. (2002), Discrepancies in Self/Subordinates' Perceptions of Leadership Behavior Leader's Gender, Organizational Context, And Leader's Self-Monitoring. Group and Organization Management, Vol. 27 No. 2, pp. 226244.

Bradley, H. (1989), Men's Work, Women's Work: A Sociological History of the Sexual Division of Labour in Employment, Cambridge: Polity Press.

Broadbridge, A. (1997), "Why Earnings Differentials are Different for Men and Women in Retailing”, The Service Industries Journal, Vol. 17 No. 2, pp. 221-236.

Broadbridge, A. (1999), "A profile of female retail managers: some insights", The Service Industries Journal, Vol. 19 No. 3, pp. 135-61.

Broadbridge, A. (2007), "Dominated by women: managed by men? The career development process of retail managers", International Journal of Retail \& Distribution Management, Vol. 35 No. 12, pp. 956-974.

Broadbridge, A., Maxwell, A., and Ogden, S. (2007), "Experiences, perceptions and expectations of retail employment for Generation Y", Career Development International, Vol. 12 No. 6, pp. 523-544.

Brockbank, A. and Airey, Y. (1994), "Women Managers in the Retail Industry", International Journal of Retail and Distribution Management, Vol. 22 No. 4, pp. 3-12.

Brooke, L., and Taylor, P. (2005), "Older workers and employment: managing age relations”, Ageing and Society, Vol. 25 No. 3, pp. 415-429. 
Bu, N. and McKeen, C. (2001), "Work goals among male and female business students in Canada and China: the effects of culture and gender", The International Journal of Human Resource Management, Vol. 12 No. 2, pp. 166-183.

Burns, P. (1997), “Hard-skills, soft-skills: undervaluing hospitality's service with a smile”, Progress in Tourism and Hospitality Research, Vol. 3 No. 3, pp. 239-248.

Cambra-Fierro, J., Berbel-Pineda, J., Ruiz-Benítez, R., and Vázquez-Carrasco, R. (2013), "Analysis of the moderating role of the gender variable in service recovery processes", Journal of Retailing and Consumer Services, Vol. 20 No. 4, pp. 408-418.

Cejka, M. and Eagly, A. (1999), "Gender-Stereotypic Images of Occupations Correspond to the Sex Segregation of Employment”, Personality Social Psychological Bulletin, Vol. 25 No. 4, pp. 413 - 423.

Chang, J. and Travaglione, A. (2012), "Gender and Employment Structure Patterns in Australia's retail workforce: An intra-industry analysis", Australian Bulletin of Labour, Vol. 38 No. 4, pp. 315-344.

Chatman, J.A. (1991), "Matching People and Organizations: Selection and socialization in public accounting firms”, Administrative Science Quarterly, Vol. 36, pp. 459-84.

Connelly, B., Certo, S., Ireland, R., Reutzel, C. (2011), "Signaling theory: A review and assessment”, Journal of Management, Vol. 37, pp. 39-67.

Cranford, C., Vosko, L., and Zukevich, N. (2003), "The Gender of Precarious Employment in Canada”, Relations Industrielles/Industrial Relations, Vol. 58 No. 3, pp. 454-482.

Crompton, R. (2002), "Employment, flexible working and the family", British Journal of Sociology, Vol. 53 No. 4, pp. 537-58.

Daily, C., Certo, S., and Dalton, D. (2005), "Investment bankers and IPO pricing: Does prospectus information matter?”, Journal of Business Venturing, Vol. 20, pp. 93-111.

Das, G. (2014), "Impacts of retail brand personality and self-congruity on store loyalty: the moderating role of gender", Journal of Retailing and Consumer services, Vol. 21 No. 2, pp. 130-138.

Deaux, K. (1984), "From individual differences to social categories: analysis of a decade’s research on gender”, American Psychologist, Vol. 39 No. 2, pp. 105-16.

Donavan, D., Brown, T., and Mowen, J. (2004), "Internal benefits of service workercustomer orientation: job satisfaction, commitment, and organizational citizenship behaviors”, Journal of Marketing, Vol. 68 No. 1, pp. 128-146 
Durcikova, A. and Gray, P. (2009), "How knowledge validation processes affect knowledge contribution”, Journal of Management Information Systems Vol. 25, pp. 81107.

Finch, J. and Groves, D. (1983), “Introduction”, in Finch, J and D Groves (eds) A labour of Love: Women, Work and Caring, London: Routledge and Kegan Paul, pp. 1-10.

Fischer, E., Gainer, B., and Bristor, J. (1997), “The sex of the service provider: Does it influence perceptions of service quality?”, Journal of Retailing, Vol. 73 No. 3, pp. 361382.

Foster, C. (2004), "Gendered retailing: a study of customer perceptions of front-line staff in the DIY sector”, International Journal of Retail and Distribution Management, Vol. 32 No. 9, pp. 442-447.

Freathy, P. and Sparks, L. (1995), “Developments in the superstore labour market”, The Service Industries Journal, Vol. 13, pp. 65-79.

Gabriel, P. and Schmitz, S. (2007), “Gender Differences Among Workers: Gender differences in occupational distributions among workers”, Monthly Labour Review, Vol. 19, pp. 19-24.

Grönroos, C. (1984), A service quality model and its marketing implications. European Journal of marketing, Vol. 18 No. 4, pp. 36-44.

Gummesson, E. (1987), Quality - The Ericsson Approach, Ericsson, Stockholm

Harris, L., Foster, C., and Whysall, P. (2007) "Maximising women's potential in the UK's retail sector”, Employee Relations, Vol. 29 No. 5, pp. 492-505.

Hennig-Thurau, T. (2004), Customer orientation of service employees: Its impact on customer satisfaction, commitment, and retention. International Journal of Service Industry Management, Vol. 15 No. 5, pp. 460-478.

Hochschild, A. (1983), The Managed Heart: Commercialisation of Human Feeling, London: University of California Press.

Iacobucci, D., and Ostrom, A. (1993), Gender differences in the impact of core and relational aspects of services on the evaluation of service encounters. Journal of Consumer Psychology, Vol. 2 No. 3, pp. 257-286.

Jackson, V., Stoel, L., \& Brantley, A. (2011), “Mall attributes and shopping value: Differences by gender and generational cohort”, Journal of Retailing and Consumer Services, Vol. 18 No. 1, pp. 1-9. 
Jaworski, B. and Kohli, A. (1993), “Market orientation: antecedents and consequences”, The Journal of Marketing, Vol. 57 No. 3, pp. 53-70.

Johnstone, R. and Grafen, A. (1993), “Dishonesty and the handicap principle”, Animal Behaviour, Vol. 46, pp. 759-764.

Kerfoot, D. and Korczynski, M. (2005), "Gender and Service: New Directions for the Study of “Front-Line Service Work”, Gender, Work and Organization, Vol. 12 No. 5, pp. 397-399.

Kmec, J. (2008), “The Process of Sex Segregation in a Gender-Typed Field: The Cases of Males Nurses”, Sociological Perspectives, Vol. 51 No. 2, pp. 259-279.

Korczynski, M. (2002), Human Resource Management in Service Work, Basingstoke: Palgrave.

Ladhari, R., and Leclerc, A. (2013), "Building loyalty with online financial services customers: Is there a gender difference?”, Journal of Retailing and Consumer Services, Vol. 20 No. 6), pp. 560-569.

Loughlin, C. and Barling, J. (2001) "Young workers' work values, attitudes, and behaviours", Journal of Occupational and Organizational Psychology, Vol. 74, pp. 543558.

Lynch, S. (2002), “Gender Segregation in the Retail Industry”, DTI Gender Research Forum, DTI Conference Centre, November 8.

Marchington, M. (1995), "Shopping down different aisles - a review of the literature on human resource management in food retailing", Journal of Retailing and Consumer Services, Vol. 3, pp. 21-32.

Martin, L. and Groves, J. (2002), Interviews as a selection tool for entry-level hospitality employees. Journal of Human Resources in Hospitality and Tourism, Vol. 1 No. 1, pp. 41-47.

Mathies, C., and Burford, M. (2011), Customer service understanding: gender differences of frontline employees. Managing Service Quality, Vol. 21 No. 6, pp. 636-648.

Mattila, A., Grandey, A., and Fisk, G. (2003), "The interplay of gender and affective tone in service encounter satisfaction”, Journal of Service Research, Vol. 6 No. 2, pp. 136-43.

Maxwell, G. and Ogden, S. (2006), "Career development of female managers in retailing: inhibitors and enablers”, Journal of Retailing and Consumer Services, Vol. 13, pp. 11120.

McColl-Kennedy, J., Daus, C., and Sparks, B. (2003), “The role of gender in reactions to service failure and recovery”, Journal of Service Research, Vol. 6 No. 1, pp. 66-82. 
McDonald, P., Bradley, L. and Brown, K. (2008), "Visibility in the workplace: still an essential ingredient for career success?”, The International Journal of Human Resource Management, Vol. 19 No. 12, pp. 2198-2295.

McGauran, A. (2000), "Vive La Différence: The Gendering of Occupational Structures in a Case Study of Irish and French Retailing”, Women's Studies International Forum, Vol. 23 No. 5, pp. 613-627.

McIntyre, J. (2000), "Women in part-time management in the retail sector: the employees’ viewpoint”, Personnel Review, Vol. 29, pp. 637-53.

McNeill, L. S., \& Douglas, K. (2011), "Retailing masculinity: Gender expectations and social image of male grooming products in New Zealand”, Journal of retailing and consumer services, Vol. 18 No. 5, pp. 448-454.

Mortimer, G., \& Clarke, P. (2011), "Supermarket consumers and gender differences relating to their perceived importance levels of store characteristics", Journal of Retailing and Consumer Services, Vol. 18 No. 6, pp. 575-585.

Narver, J. and Slater, S. (1990), "The effect of a market orientation on business profitability”, The Journal of Marketing, Vol. 54, pp. 20-35.

Ngo, H. (2000), “Trends in occupational sex segregation in Hong Kong”, International Journal of Human Resource Management, Vol. 11 No. 2, pp. 251-263.

Ngo, H. (2002), “Part-time employment in Hong Kong: a gendered phenomenon?”, The International Journal of Human Resource Management, Vol. 13 No. 2, pp. 361-377.

Parasuraman, A., Zeithaml, V., and Berry, L. (1985), “A conceptual model of service quality and its implications for future research”, The Journal of Marketing, Vol. No. 4, pp. 41-50.

Perkins, S. and Hendry, C. (2005), “Ordering top pay: Interpreting the signals”, Journal of Management Studies, Vol. 42, pp. 1443-1468.

Pettinger, L. (2005), “Gendered Work Meets Gendered Goods: Selling and Service in Clothing Retail”, Gender, Work and Organization, Vol. 12 No. 5, pp. 460-478.

Pilcher, K. (2007), “A Gendered 'Managed Heart’? An Exploration of the Gendering of Emotional Labour, Aesthetic Labour, and Body Work in Service Sector Employment”, Reinvention: a Journal of Undergraduate Research, Vol. 1 No. 1, pp. 1-13.

Pini, B. and McDonald, P. (2008), "Men, masculinities and flexible work in local government”, Gender in Management: An International Journal, Vol. 23 No. 8, pp. 598612. 
Regine, B. (2011), "Soft is the new hard, and women lead the way”, Forbes, 30 March, available at: http://www.forbes.com/sites/85broads/2011/03/30/soft-is-the-new-hard-asin-skills-and-women-lead-the-way

Ridgeway, C. and Correll, S. (2004), "Unpacking the Gender System: A Theoretical Perspective on Gender Beliefs and Social Relations”, Gender and Society, Vol. 18, pp. 510-31.

Schimdt, R. and Parker, C. (2003), "Diversity in independent retailing: Barriers and Benefits - Impacts of gender”, International Journal of Retail and Distribution Management, Vol. 31 No. 8, pp. 428-439.

Shephard, A., Kinley, T., and Josiam, B. (2014), "Fashion leadership, shopping enjoyment, and gender: Hispanic versus, Caucasian consumers' shopping preferences”, Journal of Retailing and Consumer Services, Vol. 21 No. 3, pp. 277-283.

Sheridan, A. (2004), “Chronic Presenteeism: The Multiple Dimensions to Men's Absence from Part-Time Work”, Gender, Work and Organization, Vol. 11 No. 2, pp. 207-225.

Simpson, M., Dawkins, P., and Madden, G. (1997), "Casual Employment in Australia: Incidence and Determinants”, Australian Economic Papers, Vol. 36 No. 69, pp. 194-205.

Sirianni, C. and Negrey, C. (2000), “Working Time as Gendered Time”, Feminist Economics, Vol. 6 No. 1, pp. 59-76.

Smithson, J. and Stokoe, E. (2005), "Discourses of Work-Life Balance: Negotiating “Gender blind” Terms in Organizations”, Gender, Work and Organization, Vol. 12(2, pp. 147-168.

Sparks, L. (1991), "Employment in DIY superstores”, The Service Industries Journal, Vol. 11 No. 3, pp. 304-23.

Sparks, L. (1992), “Restructuring Retail Employment”, International Journal of Retail and Distribution Management, Vol. 20 No. 3, pp. 12-20.

Taylor, S. and Tyler, M. (2000), "Emotional Labour and Sexual Difference in the Airline Industry”, Work, Employment and Society, Vol. 14 No. 1, pp. 77-95.

Tikka, J. (1999), “Women and Jobs”, Monthly Labour Review, Vol. 12 No. 10, p. 38.

Tomlinson, J. (2007), "Employment regulation, welfare and gender regimes: a comparative analysis of women's working-time patterns and work-life balance in the UK and the US”, The International Journal of Human Resource Management, Vol. 18 No. 3, pp. 401-415. 
Toynbee, P. (2006), Personal correspondence via an interview filmed as part of a forthcoming film for The Reinvention Centre for Undergraduate Research entitled 'Learning to Labour in Higher Education' 27 October, London.

Wanrooy, B., Jakubauskas, M., Buchanan, J., Wilson, S., and Scalmer, S. (2008), Australia at work, working lives: statistics and stories, University of Sydney, Sydney.

Warren, T. (2004), "Working part-time: achieving a successful "work-life” balance?”, The British Journal of Sociology, Vol. 55 No. 1, pp. 99-122.

White, G. (2007), "Family-friendly Employment Policies and Practices: An East-West Perspective on Work Life Balance", $14^{\text {th }}$ International Employment Relations Association Conference, 19-23 June 2006, Hong Kong: Hong Kong Baptist University.

Zhang, Y., Wiersema, M. (2009), "Stock market reaction to CEO certification: The signaling role of CEO background”, Strategic Management Journal, Vol. 30, pp. 693710. 